\title{
OS IMAGINÁRIOS URBANOS DAS PESSOAS JOVENS RESIDENTES EM HEREDIA, COSTA RICA: UMA APROXIMAÇÃO DESDE AS PRÁTICAS SÓCIO-ESPACIAIS
}

\section{THE IMAGINARY OF URBAN YOUNG PEOPLE LIVING IN HEREDIA: AN APPROACH FROM THEIR SOCIO- SPATIAL PRACTICES}

\author{
Iliana Araya Ramírez ${ }^{1}$ \\ ${ }^{1}$ Universidad Nacional (UNA), Heredia, Costa Rica
}

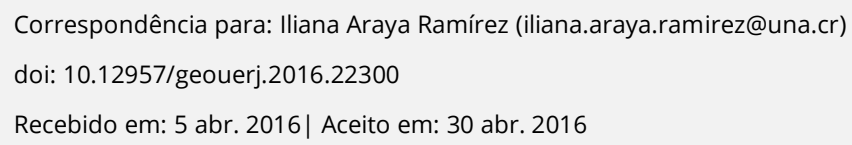

\section{RESUMO}

O artigo mostra os resultados de um estudo exploratório sobre a forma como os jovens na cidade de Heredia constroem os diferentes imaginários urbanos desde as práticas sócio-espaciais em sua viagem biográfica da infância para a idade adulta. O objetivo é compreender as práticas socioespaciais que recriam imaginário urbano na construção subjetiva da cidade, a fim de estabelecer a relação transformações urbanas. Os dados foram coletados por meio de relatos de vida dos jovens, em sua maioria entre 20 e 30 anos, residentes na cidade de Heredia, em abril de 2015. A partir dos dados obtidos serão analisados quatro imaginários: o imaginário patrimonial, imaginária cafeteiro, imaginário comercial e imaginário da inseguridade. Este artigo promove uma possibilidade de discussão de uma orientação de trabalho para futuras pesquisas na área trazendo uma forma metodológica que trabalhe com a questão dos imaginários urbanos.

Palavras-chave: Imaginários urbanos, práticas socioespaciais, jovens, relato de vida, Heredia.

\begin{abstract}
This article shows the results of a study about how young people in the city of Heredia construct different urban imaginaries along their biographical itinerary. The objective is to understand the socio-spatial practices that recreate the urban imaginaries, shaping the subjective construction of the city. The ultimate goal is to establish the relationship between urban transformations and the sense of place (commitment and sense of belonging). The data were collected through life stories to young people, mostly with university studies, between 20 and 30 years old, living in the city of Heredia, during April 2015. Based on the data obtained, four imaginary categories are proposed: heritage imaginary (historical-affective space), imaginary coffee plantation (productive-agrarian space), imaginary commercial (business transactions space) and imaginary of insecurity (urban mobilization space). This article seeks to establish a methodology to understand the urban imaginaries construction and to promote its utilization as a necessary tool in planning processes as well as in the definition of social policies.
\end{abstract}

Keywords: Urban imaginary, socio-spatial practices, young people, life story, Heredia.

\section{INTRODUÇÃO}

Neste artigo, apresenta-se os resultados das práticas socioespaciais de trabalho, estudo, mobilização e recreação configuram diferentes imaginários urbanos, segundo o itinerário biográfico das pessoas jovens, desde a infância até a vida adulta. 
Neste estudo partiu da premissa que a construção subjetiva do lugar é elaborada ao recriar o itinerário biográfico, a permanência de diversos imaginários urbanos que constitui o ponto de partida para compreender como os jovens habitam a cidade. Assim, a cidade, como lugar, é construída socialmente, a partir do intercâmbio simbólico e recíproco entre as pessoas e o lugar habitado, praticado e vivido no cotidiano (LINDÓN, 2007 citando a LEE, 1978).

Heredia é o espaço urbano onde se desenvolve esta pesquisa, conhecida como "A cidade das Flores" também, "Heredia cidade cultural; fundada em 1824 (MELÉNDEZ \& RAMÍREZ, 2001) uma cidade pequena com apenas $2,83 \mathrm{Km}^{2}$ se encontra uma megalópole no interior da Grande área metropolitana de Costa Rica. Conforme uma mistura de elementos contrastantes entre tradicionais e modernos; de um lado o centro histórico com suas edificações de alto valor patrimonial muito ligado ao simbolismo tradicional desde o estabelecimento da cidade. De outro lado, uma "Heredia pós-moderna" com zonas residenciais e de comércio que representam a capital global. A tensão entre ambos elementos nos convida a pensar: quais são as representações hegemônicas e contra hegemônicas, por parte das pessoas jovens da cidade de Heredia?

Da mesma maneira, a articulação de elementos tradicionais com aqueles pós-modernos planteia o questionamento: como as pessoas jovens elaboram a construção social do espaço urbano? É a partir das representações espaciais do que a subjetividade dos sujeitos sociais conduz-nos a plantear o porquê de suas ações e as implicações das práticas sócioespaciais na construção subjetiva da cidade e como as características morfológicas do espaço incidem nas práticas.

O propósito desta investigação consiste em compreender: quais são as práticas sóciosespaciais na construção dos imaginários urbanos abordada desde as narrativas dos jovens heredianas que ajudam na construção da cidade? A natureza do problema de investigação conduz na seleção do enfoque qualitativo desde o construtivismo geográfico, o qual forma parte do giro cultural proveniente da geografia humanista, e recupera os conceitos de experiência espacial e construção social do lugar 
(LINDÓN, 2007). Assim, a cidade de Heredia é interpretada desde as geografias dos jovens que constroem os lugares no cotidiano e esses configuram sua identidade.

Desde a Geografia Humana, os enfoques qualitativos e interpretativos permitem avançar na compreensão dos significados e simbolismos que outorgam os sujeitos à cidade que habitam (LINDÓN, 2008). No caso da cidade de Heredia indagam-se a significação dos lugares, segundo as práticas espaciais e a experiência espacial dos jovens que habitam a cidade. Dessa forma, aborda-se a subjetividade do mundo vivido, as conexões entre os significados e os ritmos espaço temporais nos lugares (MILLÁN, 2004).

Nesta investigação se desenvolve em a perspectiva do tipo etnosociológico, ou seja, uma investigação empírica com trabalho de campo, a qual utiliza objetos caracterizados pela homogeneização e diferenciação (BERTAUX, 2005). De um lado, a homogeneização evidencia-se no processo de globalização que afeta as cidades latino-americanas, como acontece com a Cidade de Heredia. Neste sentido, diminui as diferenças espaciais segundo a influência das tecnologias da informação, as estratégias transnacionais empresariais, as políticas do mercado e as consequências do imperialismo cultural (JANOSCHKA, 2011).

De outro lado, se produze uma diferenciação funcional do espaço e algumas das manifestações deste processo se expressam na abertura de centros comerciais, franquias internacionais tanto de comércio como de educação superior, localizados nas principais vias de circulação. Também emergem áreas residências destinadas às classes sociais com maior poder aquisitivo, em detrimento de aquelas habitadas por sectores populares; o qual acarreia uma diferenciação espacial. No entanto, a diferenciação refere-se aos processos de resistência e invenção das tradições das pessoas jovens heredianas. Para (BERTAUX, 2005) la perspectiva etnosociológica “...propone una forma de investigación empírica adaptada a la captación de la lógica propia" (p.16), en este caso se intenta capturar los imaginarios urbanos y las prácticas espaciales que los reproducen. 
A técnica utilizada foi o relato de vida que oferece uma dimensão diacrônica para capturar o desenvolvimento biográfico (BERTAUX, 2005) e a configuração das práticas espaciais dos jovens em seu entorno urbano e contexto sociocultural que remetem as formas de habitar a cidade e se expressa nas atividades cotidianas de trabalho, movimentos, consumo, recreação, expressadas em sua corporeidade e sua espacialidade. Daí, que a utilização da técnica do relato de vida pode conduzir ao significado, que contém para a pessoa, as práticas espaciais (LINDÓN, 2008). A técnica do relato de vida em sua forma narrativa consiste em contar a outra pessoa, um incidente de sua experiência de vida. A característica fundamental é descrever a estrutura diacrônica da vivência (BERTAUX, 2005).

As práticas socioespaciais asseguram a continuidade e coesão do espaço social, de maneira que quando os sujeitos têm relações espacialmente se produzem comportamentos específicos (LEFEBVRE, 2013). Tais práticas classificam-se em dois tipos: aquelas que correspondem ao deslocamento do sujeito e as outras as formas de permanecer nos lugares, ambas são repetições rotineiras na vida cotidiana, no uso e significado do espaço (LINDÓN, 2012).

\section{As praticas socioespaciais na construção do lugar}

O conceito de lugar é retomado por Yi Fu TUAN (1997) tanto que a conceptualização de espaço se associa com amplitude, falta de limites e liberdade, enquanto que o de lugar aparece com uma carga de significados que as pessoas outorgam-lhe quanto ao sensorial, perceptual e como experiência da pessoa. Para TUAN (1977) o lugar faz referência a aqueles espaços delimitados que apresentam certeza e segurança para os sujeitos que o compartem e adquirem um sentido simbólico por meio da objetivação dos elementos, os quais são codificados em redes de comunicação e as relações com o entorno (LINDÓN, 2012, LINDÓN, AGUILAR \& HIERNAUX, 2006).

Em seu livro Topofilia, Tuan aborda a dimensão sensível do espaço quanto ao sensorial, perceptual e como experiência da pessoa. Esse autor reconstrói o conceito de topofilia, no qual os sujeitos outorgam subjetividade ao espaço percebido, apropriado, habitado e significado. Quer dizer, as formas de 
permanecer nos lugares estão relacionadas na topofilia, ou seja: o vínculo afetivo das pessoas para um entorna material ou para um lugar. Para (TUAN, 2007) “A topofilia não é a mais forte das emoções humanas. Quando chega a sê-lo, podemos estar seguros que o lugar ou o entorno se transformou em portadores de acontecimentos de grande carga emocional o que se percebe como um símbolo" (p. 130), embora os lugares possam provocar rechaço ou topofobia. Por isso, a capacidade de observação está vinculada fortemente com nossas experiências.

Segundo TUAN a perspectiva experiencial, entendida como as formas de compreender e organizar a realidade envolve o uso dos sentidos da vista, o olfato, o gosto e o tato para formar uma codificação e simbolizar o espaço. A experiência espacial produz a aprendizagem espacial que permite compreender os lugares dos quais formamos parte. Essas representações envolvem sentimentos e valores das pessoas com respeito ao lugar; assim quando utilizamos os sentidos para olhar e ouvir, não faz referência ao que observamos ou ouvimos, senão à forma em que interpretamos ou escutamos. 0 apego ou desapego ao lugar constitui o repositório de nossas memórias que nos produzem alegria, nostalgia, temor, tristeza, insegurança, segurança, sem experimentá-los pessoalmente.

A construção social dos lugares, pela ação dos sujeitos sociais, a partir das práticas espaciais está filtrada de emoções, apegos ou desapegos que ocasionam uma variedade de sentimentos pelos lugares. Assim mesmo, a espacialidade da prática está acompanhada de sentimentos pelos lugares que variam entre o temor, a nostalgia, a segurança, insegurança, assim como lembranças tanto agradáveis como desagradáveis (LINDÓN, 2009). "De tal modo que e as práticas espaciais, os significados, as emoções e a afetividade integram uma trama complexa que se estende experiencialmente, e dentro da qual se desenvolve a biografia do sujeito" (LINDÓN, 2009, p. 13).

\section{As práticas espaciais e o imaginário urbano na construção social da cidade}

A construção socioespacial da cidade se inicia a partir das práticas espaciais dos sujeitos expressadas em sua corporeidade e sua espacialidade. Tais práticas configuram a imaginação geográfica que é 
plasmada nos imaginários urbanos, dessa forma, a morfologia do espaço incide na subjetividade dos sujeitos que habitam a cidade, e às vezes a subjetividade incide nas práticas de apropriação do espaço.

Segundo DURAND (1994) a relação de materialidade e imaterialidade na conceptualização do imaginário está expressa como a representação, à simbolização de onde emerge os medos e as esperanças e funciona sobre a base da representação, como uma forma de traduzir a imagem mental ou a realidade material (Citado em Daniel HIERNAUX, 2007).

Nas palavras de Alicia LINDÓN “a construção social dos distintos lugares que integram a cidade é um processo constante de manufaturarão do espaço que realizam as pessoas em interação umas com as outras, orientando suas práticas espaciais através de uma trama de sentido que denominamos imaginários urbanos" (2007, p. 32). Segundo DURAND e LINDÓN, a configuração espacial é o substrato a partir do qual se constroem nos imaginários urbanos, já que o simbolismo que evoca o lugar prove de sua morfologia.

Conforme a visão antropológica de Raúl NIETO (1998) que coincide com a de LINDÓN, admitem ambos que a Geografia e a Sociologia retomam a ação das práticas cotidianas. "O imaginário urbano constitui uma dimensão por meio da qual os distintos habitantes de uma cidade representam, significam e dão sentido as suas distintas práticas cotidianas no ato de habitar; constitui una dimensão na qual se estabelecem distintas identidades, mas, também, se reconhecem diferenças" (p. 25). Em tais práticas cotidianas, o acionar cotidiano dos sujeitos encaminha a construção social da cidade.

As práticas espaciais abarcam a produção e reprodução em cada localização particular de acordo com o conjunto de características de cada formação social. Dessa maneira, a prática espacial assegura continuidade e algum grau de integração. Em termos do espaço social, cada sujeito interatua com o espaço e a coesão garante um nível de competência e de comportamento (LEFEBVRE, 2013). 
Para que o estudo dos espaços exteriores produza alguns rastros acerca das formas de produção e reprodução da cidade, LINDÓN (2009) recorre às análises das microssituações, as quais oferecem indícios de processos de maior amplitude, como a reprodução e produção socioespacial da cidade, desde a visão da passagem holográfica, a qual fez "possível que una microssituação falasse de outras situações da cidade, porque sempre os atores territorializados que a protagonizam em uma situação, reproduzem códigos de comportamento ou de interpretação que procedem de outros lugares e tempos, ou melhor, recriam códigos em diálogo ou em confrontação com outros lugares e tempos nos quais têm sido parte de algo" (LINDÓN, 2009, p.14).

Finalmente, os imaginários urbanos como um processo de construção social permanente são focalizados desde a dimensão espacial (LINDÓN, 2007); assim a geografia humana contribui na apreensão da subjetividade e a tradução desses imaginários na produção do espaço urbano (LINDÓN \& HIERNAUX, 2012). Tais imaginários configuram as representações espaciais do espaço concebido e espaço vivido, aqueles compostos de elementos concretos, ideológicos e imaginários. Por sua vez, os imaginários urbanos, são construções subjetivas socialmente construídas, donde os elementos afetivos e emocionais estruturam as práticas espaciais, ou seja, as formas de atuar no território (LINDÓN, 2009).

\section{METODO}

A reconstrução da realidade social das práticas socioespaciais dos jovens heredianos se elabora por meio da investigação qualitativa, em uma perspectiva etnosociológica, com a técnica do relato de vida. O procedimento analítico neste estudo foi orientado na "teoria fundamentada" (ground theory) a qual deriva dos dados escolhidos sistematicamente e analisado em um processo de pesquisa. "Neste método, a recolecção de dados, o analise e a teoria emerge da relação entre sim" (STRAUSS \& CORBIN, 2002 , p.13). A teoria fundamentada é vasada dos dados que geram conhecimento e acrescentam a compreensão para orientar a ação da pesquisa. 
Nesta pesquisa esta constituída de quatro etapas: na primeira é a aproximação teórica conceitual do objeto de estúdio, na segunda a imersão ao trabalho de campo, a terça fase a recolecção da informação, é na ultima analise e sistematização dos resultados. A etapa de aproximação teórica-conceitual do objeto de estudo requereu-se da revisão do estado da questão para o enriquecimento das categorias fundamentais, foram consultadas as investigações recentes e as teorias chaves do tema.

A imersão ao trabalho do campo foi feita a partir indagações com pessoas concidadãs que tivessem familiares nascidos na Heredia, com idades entre 20 e 30 anos, residentes na cidade de Heredia desde seu nascimento. Logo se o recorre às redes das pessoas jovens para contatar a outros, familiares ou vivinhos. A seleção das pessoas jovens seguiu a tipologia urbana da cidade de Heredia desenhada nesta investigação:

- $\quad$ Espaço tradicional (centro histórico).

- $\quad$ Espaço pós-moderno globalizado (entrada a Heredia, "calle do colesterol" (rua onde estão localizados restaurantes de comida rápida: Mc Donalds, Burger King, Taco Bell, KFC, Pizza Hut, Hot Dogs, etc).

- $\quad$ Espaço recreativo (Estadio Rosabal Cordero- Palacio de los Deportes)

- $\quad$ Espaço residencial

A partir desta tipologia, foram escolhidas três pessoas jovens de a zona comercial e quatro da zona residencial.

$\mathrm{Na}$ recolecção da informação, em março de 2015, foram recolhidos sete relatos de vida de quatro mulheres e três homens, seis dos jovens são universitários, desses dois exercem a profissão, um tem mestrado e trabalha como professor de Economia da universidade, outra trabalha na empresa transnacional e atualmente e licenciada em Administração. Três mulheres cursam aulas para terminar suas licenciaturas, nas áreas de Engenheira de Sistemas, Administração de Empresas e Planificação Econômica e Social. Um jovem cursa aulas de terceiro nível das Ciências Geográficas. Só um jovem 
leva aulas no Ensino Médio. Os jovens entrevistados são residentes dos bairros El Carmen, Fátima, Bernardo Benavides, Los Ángeles e Barrio Corazón de Jesús (Figura1). A entrevista tem uma duração aproximada de uma hora, para a qual se construiu um guia de perguntas do relato. Assim mesmo, foi solicitada a cada um dos entrevistados licença especial para a gravação e a assinatura do consentimento informado. Para cada relato de vida foi assinado um código (R.J.1, R.J.2, R.J.3, R.J.4, R.J.5, R.J.6, e R.J.7).

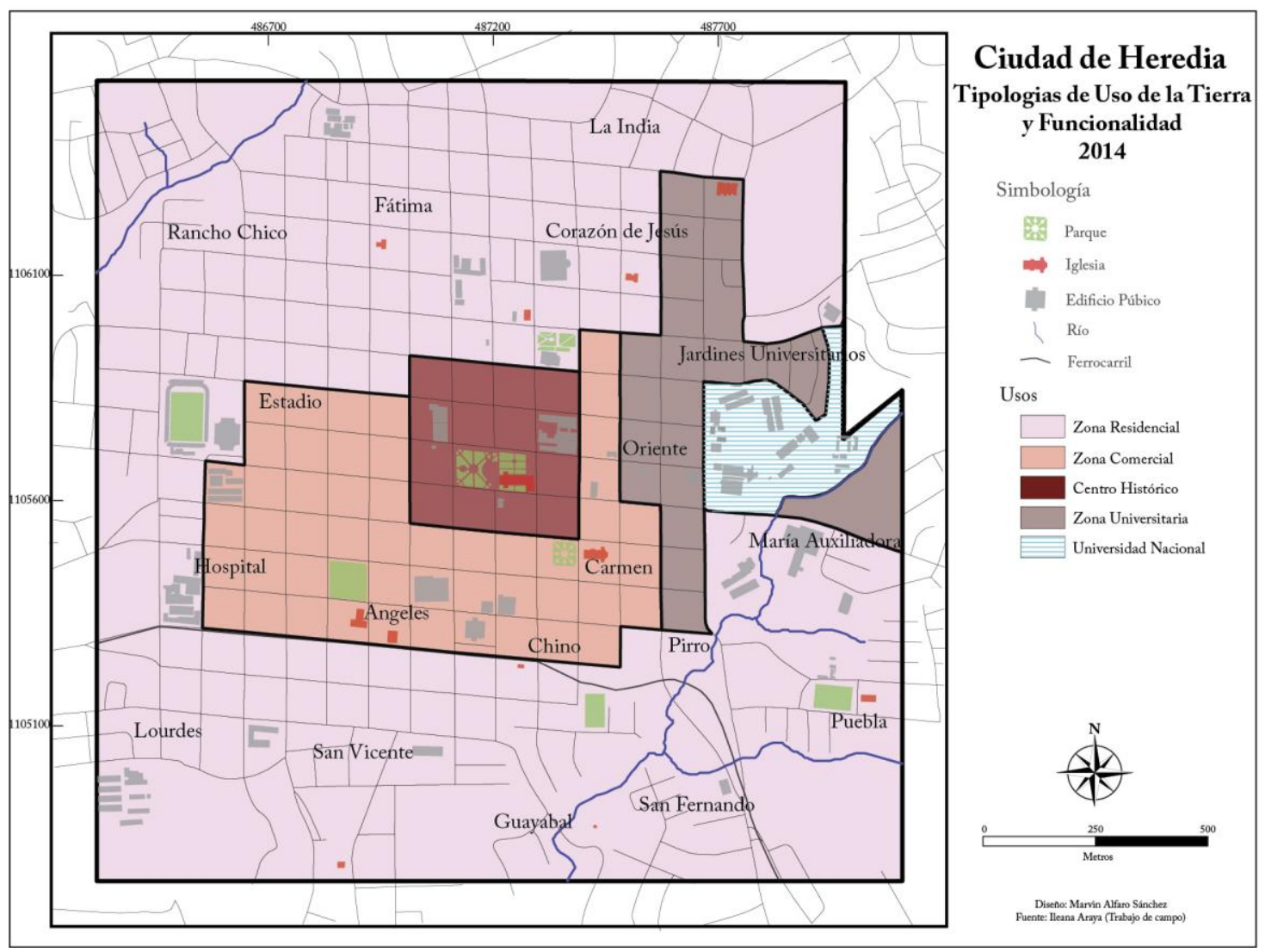

Figura 1. Tipologias de uso da terra e funcionalidade na cidade de Heredia, 2014.

$\mathrm{Na}$ etapa de análise e sistematização dos resultados foram lidas todas as transcrições dos relatos de vida, logo o procedimento constou em um ordenamento conceitual, o seja, "organização dos dados em categorias discretas e segundo suas propriedades e dimensões" (STRAUSS \& CORBIN, 2002, p.21) que são descritas para dilucidar nesta categoria. A reconstrução da cidade de Heredia foi elaborada a partir da narrativa biográfica, por parte das pessoas jovens, segundo as categorias, dimensões e subcategorias consideradas no quadro 1. As categorias consideram as propriedades das mesmas, ou 
seja, condições que mudam as estratégias, táticas e principais consequências e se tomam notas que surgem da codificação. A vinculação metodológica entre o imaginário urbano e as praticas espaciais com os relatos de vida está seguindo a CORDERO (2014) como se apresenta no quadro 1.

\begin{tabular}{|c|c|c|c|}
\hline Categorias & Infância & Adolescência & Vida adulta \\
\hline \multirow[t]{3}{*}{$\begin{array}{l}\text { Imaginário } \\
\text { urbano }\end{array}$} & $\begin{array}{l}\text { Imaginário urbano da infância: } \\
\text { Imaginário patrimonial Tradicional } \\
\bullet \quad \text { Educativo } \\
\text { - } \quad \text { Lúdico } \\
\text { - } \quad \text { Cultural } \\
\quad \text { Imaginário cafeteiro } \\
\text { Uso do espaço público } \\
\text { Lugares preferidos } \\
\text { Lugares menos preferidos } \\
\text { Atividades favoritas } \\
\text { Lugares frequentados } \\
\text { Lugares de jogos } \\
\text { Escola } \\
\text { Uso do espaço cafeteiro }\end{array}$ & 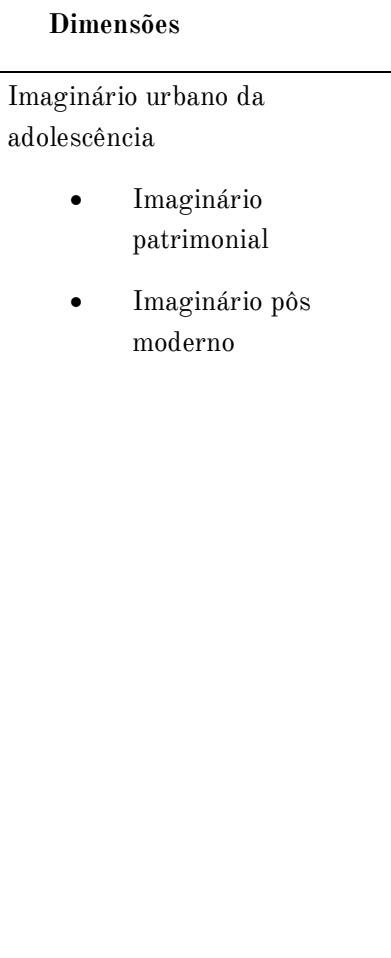 & $\begin{array}{l}\text { Imaginário urbano da } \\
\text { vida adulta }\end{array}$ \\
\hline & \multicolumn{3}{|c|}{ Subcategorias } \\
\hline & $\begin{array}{l}\text { Uso do espaço público } \\
\text { Lugares preferidos } \\
\text { Lugares menos preferidos } \\
\text { Atividades favoritas } \\
\text { Lugares frequentados } \\
\text { Lugares de jogos } \\
\text { Escola } \\
\text { Uso do espaço cafeteiro }\end{array}$ & $\begin{array}{l}\text { Transformação do espaço } \\
\text { urbano } \\
\text { Uso comercial } \\
\text { Uso residencial } \\
\text { Desparamento de cafezais } \\
\text { Lugares de comidas rápidas } \\
\text { Desaparecimento de padarias } \\
\text { tradicionais }\end{array}$ & $\begin{array}{l}\text { Imaginários do medo } \\
\text { Lugares inseguros } \\
\text { Lugares de assaltos } \\
\text { Experiências de robôs } \\
\text { Práticas de } \\
\text { sobrevivência: leitura do } \\
\text { entorno } \\
\text { Percursos descartados }\end{array}$ \\
\hline \multirow{3}{*}{$\begin{array}{c}\text { Praticas sócio } \\
\text { espaciais }\end{array}$} & Construção subjetiva do lugar & \begin{tabular}{l}
\multicolumn{2}{c}{ Dimensões } \\
\\
Vantagens de \\
Heredia
\end{tabular} & $\begin{array}{l}\text { Desvantagens de viver } \\
\text { em Heredia }\end{array}$ \\
\hline & \multicolumn{3}{|c|}{ Subcategorias } \\
\hline & Tranquilo & Lugar central & Insegurança \\
\hline
\end{tabular}




\begin{tabular}{|l|l|l|l|}
\hline Categorias & \multicolumn{1}{|c|}{ Infância } & Adolescência & Vida adulta \\
\hline & Lúdico & Cercania de shoppings & Congestão viária \\
& Seguro & & Cobilidade \\
& Sujo consumo & & \\
& Evoca lembranças & & \\
& Congestionado & &
\end{tabular}

Figura 4. Itinerário biográfico segundo as praticas sócio espaciais que constroem o imaginário urbano na cidade de Heredia, 2015. Fonte: Elaboração própria, segundo CORDERO, 2014.

A codificação dos relatos de vida foi elaborada por meio da microanálise "linha por linha" ou se pode utilizar com palavras, orações os parágrafos (STRAUSS \& CORBIN, 2002). Foi realizada no software Atlas-ti, versão seis, a partir dos códigos preliminares indicados no quadro 1. Neste trabalho foram realizadas dois tipos de codificações. A codificação aberta consiste em "o processo analítico por meio do qual se identificam os conceitos e se descobrem suas propriedades e dimensões" parágrafos (STRAUSS \& CORBIN, 2002, p. 10). Também foi utilizada a codificação axial, nesta é definida "processo de relação entre categorias em relação de um exe" (STRAUSS \& CORBIN, 2002, p. 135).

O produto da codificação permitiu identificar e aprofundar o itinerário biográfico dos jovens entrevistados de acordo com a construção do imaginário urbano e suas práticas sócioespaciais segundo a vivência na cidade de Heredia. Esse processo consta de quatro etapas: a determinação de unidades de análises, a categorização/codificação, o estabelecimento de possíveis explicações ou conjecturas e leitura interpretativa dos resultados (GURDIÁN, 2007). A partir dos dados iniciais e as categorias previamente estabelecidas se realizou uma redução/sistematização das transcrições a dimensões manejáveis. A agrupação dos dados por meio da relação oferece explicações com maior grau de precisão e coerência. Nesta etapa foram construídos dos gráficos gerados pelo Atlas.ti que facilitou estabelecer relações lógicas entre as dimensões e suas subcategorias, por meio dos 284 códigos ao final do processo. Os gráficos permitiram identificar os padrões de acontecimentos, tais relações acrescentam a densidade e o poder explicativo da teoria (STRAUSS \& CORBIN, 2002, p. 149). A 
informação obtida para cada categoria se agrupa e se transforma em códigos, as dimensões y suas subcategorias foram trabalhadas como códigos no Atlas.ti, ao final do processo se identificaram 284.

Nessa etapa se sistematizou, elaborou e assignou segmentos das transcrições. Logo se estabeleceu as possíveis explicações e conjecturas. A interpretação é a operação principal que se complementa com a leitura interpretativa dos resultados.

\section{Algumas características da infância, a adolescência e da juventude: entre o imaginário urbano tradicional e o pós-moderno}

As mudanças globais que surgem na cidade implicam transformações urbanas, onde de forma simultânea se produzem a homogeneização e a fragmentação do espaço. Por um lado, diminui as diferenças espaciais entre as regiões e os estados, devido ao efeito homogeneizador das tecnologias da informação, as estratégias transnacionais empresariais, as políticas do mercado e as consequências do imperialismo cultural segundo (JANOSCHKA, 2011. Citando a BRENNER, 2008).

Por outro, para (Janoschka, 2002) se conduz a uma fragmentação do espaço, áreas residenciais privatizadas exclusivas, centros comerciais na periferia urbana, instalação de centros educativos privados perto das novas áreas residenciais, afastamento das áreas residenciais de classe baixa. Dessa forma, o neoliberalismo e a globalização formam parte fundamental da reestruturação econômica que incidem diretamente na política urbana e territorial, assim mesmo nos "modos de pensar, perceber, desenhar e gerenciar as cidades..." (JANOSCHKA, 2011, p. 89).

A interpretação dos relatos de vida mostra a transformação da cidade, através do itinerário biográfico dos jovens entrevistados tentam capturar o microcosmo que encerra esse espaço urbano. Na perspectiva etnosociológica "as lógicas que regem o mundo social ou o mesocosmos se dão igualmente em cada um dos microcosmos que o compõem. Observando com atenção um só, ou melhor, vários desses microcosmos, e, portanto que se consiga identificar as lógicas de ação, os mecanismos sociais, 
os processos de reprodução e de transformação, se deveria poder captar algumas das lógicas sociais do mesocosmos mesmo" (BERTAUX, 2005). Desta forma, a interpretação de tais microcosmos nos outorga pistas que podem conduzir à compreensão dos mesocosmos, nesse caso a megalópoles ou GAM.

A cidade de Heredia se interpreta desde a dimensão sensível do lugar onde os jovens interpelam à subjetividade na forma que percebem, se apropriam, e outorgam significado ao lugar que habitam. Assim proclama um jovem professor universitário...

me encanta Heredia, eu sempre visualizei Heredia como um povoado que tenta ser cidade, e talvez por isso tem se complicado tanto o trânsito, porque inclusive as próprias estradas de Heredia estão desenhadas para um povoado e não para uma cidade, mas com todo o desenvolvimento urbanístico que tem tido e também com a superpopulação, eu sinto que algumas partes de Heredia estão sendo forçadas a se comportar como uma cidade, e esse boom de que em qualquer lado existe um supermercado, um pequeno centro comercial, e todas essas coisas têm abarrotado ou talvez não, mas o fato é que Heredia não tinha a capacidade de imediato de assimilar todas essas coisas que estamos vendo, como é o caso dos engarrafamentos (R. J. 3).

A transformação do espaço urbano sobre a qual reflete este jovem economista expressa as fortes mudanças do espaço público, o qual responde à dinâmica global onde a distinção entre o público e o privado se torna imperceptível. Desta maneira, a configuração do espaço físico está influenciada pela globalização das cidades latino-americanas, nesse caso, a cidade de Heredia.

Essa forma de retratar a cidade se aborda desde o estudo do lugar, o qual recupera a experiência de conviver em um entorno específico onde às pessoas organizam um projeto e uma identidade individual e social que se estabelece no encontro com os outros de forma indissociável com o entorno. $\mathrm{O}$ encontro não é só com o entorno físico senão com os outros, onde se entrecruzam e outorgam um significado próprio e às vezes cultural dos lugares (ELZ, 2010). 
A representação da cidade se elabora de acordo com a tipologia estabelecida na figura 2, dessa forma a compreensão do imaginário urbano assume aspectos distintivos, segundo a zona onde residem os jovens entrevistados. Aqueles que moram na zona comercial da cidade opinam que Heredia nem sempre foi uma cidade limpa, pelo contrário contaminada e ruidosa. No entanto, aqueles que habitam a zona residencial a descrevem como tranquila. Assim, se expressa o jovem professor universitário: "Quando eu era pequeno, o que mais me recorda é a tranquilidade, digamos que representava e caracterizava Heredia, era uma cidade bastante calma, eu a sentia assim, não havia tanto trânsito, isso tudo é o que nos faz mais falta" (R. J. 3). Embora todos concordem com o congestionamento atual da cidade e a transformação do uso do solo, a cidade de Heredia se acelerou a partir da década do noventa do século anterior, produto da conurbação de toda a Grande Área Metropolitana de Costa Rica.

A figura 2 nos mostra o jogo e as atividades preferidas realizadas nos espaços públicos da cidade, o centro histórico, os parques, as zonas recreativas e os cafezais. Os jovens entrevistados, com idades entre 20 e 27 anos, percebem a cidade de Heredia de forma distinta, de acordo com seu itinerário biográfico. Durante a infância, em torno de 2000, todos coincidem que brincaram de um lado nas praças de futebol e no Parque Central e de outro os cafezais que ainda se encontravam em Heredia a princípios do milênio.

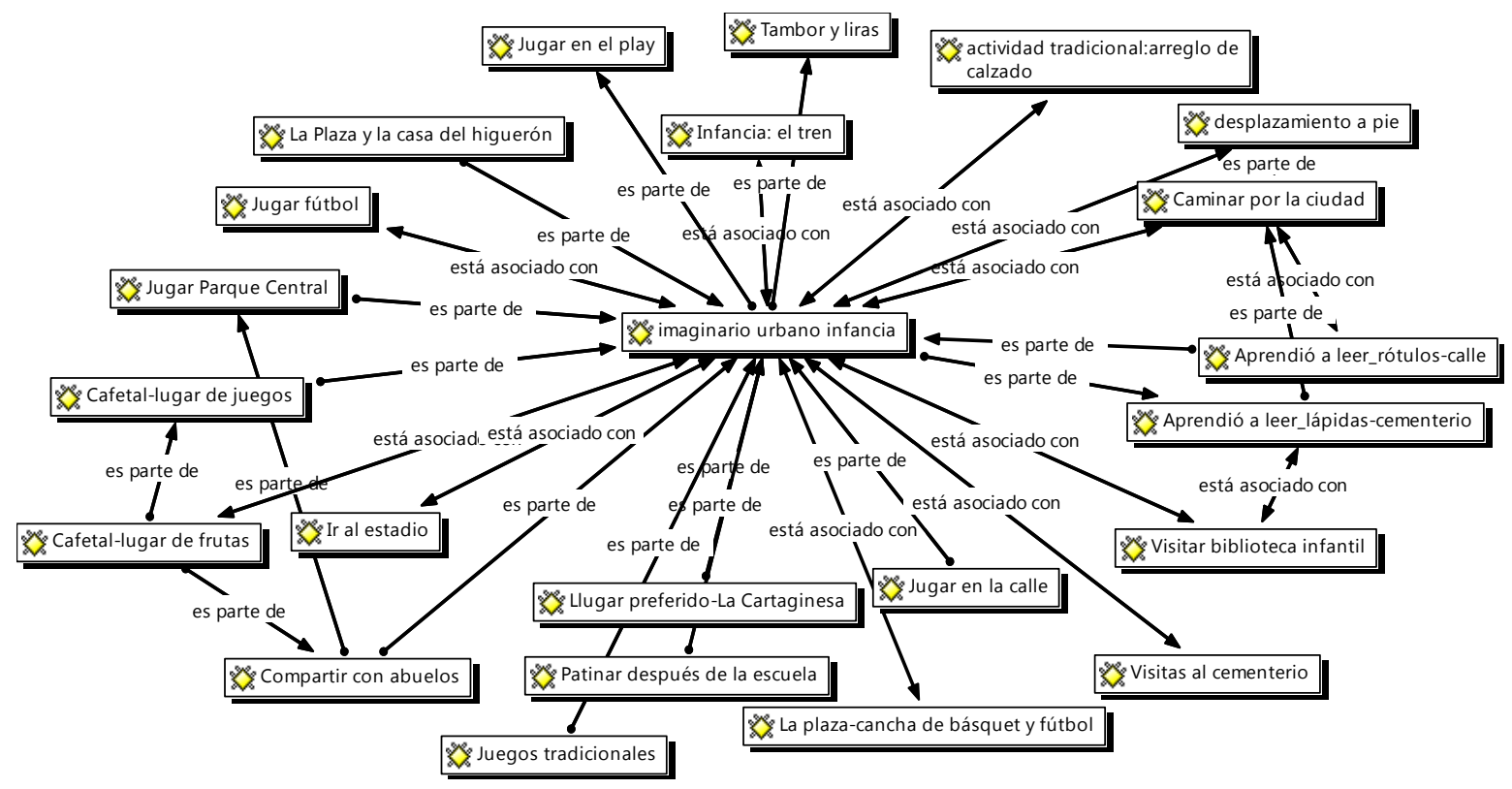

Figura 2. Imaginário urbano na infância, segundo as pessoas jovens entrevistadas, 2015. 
O imaginário urbano na infância se construiu em torno do jogo de uma atividade crucial, a experiência corporal de natureza quinéstica evoca aos lugares desde uma experiência má cognitiva. Para Carrillo (2011) a cidade aparece como um microcosmo onde conflui a realidade física e intelectual que conformam o ser humano e sua diversidade. A realidade física remete à corporeidade e a experiência espacial no espaço urbano. Como se movimentam as pessoas? Para donde se dirigem? Que cheiros emanam da cidade? Quais são as lembranças e imagens do espaço urbano? Conforme a realidade intelectual implique num processo cognitivo de apreensão do espaço urbano, dai surgirá a pergunta: Que lugares remetem experiências de aprendizagem? Por que esses lugares?

Para esta geração de jovens, brincar no espaço público durante a infância, constitui parte da marca de ser herediano, pois o Parque Central de Heredia permite reconhecer no itinerário biográfico como as práticas socioespaciais originam mudanças do imaginário da cidade tradicional e o imaginário patrimonialista conceitualizado como "o conjunto de figuras/formas/imagens a partir das quais a sociedade atual, ou pelo menos uma parte dela concebe a presença de elementos materiais ou culturais do passado em nosso passado em nosso tempo e nosso espaço hoje” (HIERNAUX, 2006, p.33).

As visitas ao Centro Histórico, ir ao Parque Central de Heredia para escutar a Banda de Heredia aos domingos, espantar as pombas e comprar um sorvete na Pops formam parte do imaginário urbano da infância, como ilustram as pessoas jovens.

O Parque Central sempre me encantou, sempre foi um dos meus parques favoritos, pois me recorda muito a meu avô, porque o meu avô me levava, ou sempre que eu lhe dizia que queria ir, ele fazia minha vontade. Ele me mimava muito, então eu lhe dizia que queria comprar algo, então recordo que o lugar onde nós íamos, era como um bazar e sempre havia que atravessar o parque Central, e aproveitávamos para comprar um sorvete...na POPS, por exemplo, que era típico ou um raspa-raspa. Na fonte, me encantava brincar e , quando não estava tão suja, sempre me encantava como estar ali naquela parte do parque, e agora também, digamos, me encanta toda essa parte do Fortín, que agora abriram, onde se tem liberdade de entrar e sentarse. Toda essa parte é magnífica, talvez seja isso que eu goste mais. (R. J. 3). Para a jovem economista viver em Heredia a vantagem era a "La POPS" 
Ir ao centro, ao parque, e assim era como nos mimava, meu tio...Todavia sigo indo à POPS... e ainda me lembro de um senhor, que eu não sei o que foi feito dele, mas faz pouco tempo que fui à POPS ele ainda estava trabalhando lá, e eu disse: olha como é a memória, pois logo que eu cheguei e vi o senhor, imediatamente o identifiquei como sendo o mesmo senhor que nos vendia os sorvetes, quando éramos crianças e já estava cheio de cabelos brancos (R. J. 1).

No caso a jovem planificadora assinala que:

“... sim! eu ia ao parque aos domingos! Sim! porque aqui só o que fazíamos era sair para brincar aqui... porque é como um ambiente diferente e aí se corre e espanta as pombas e assim, às vezes aos domingos chega uma banda, então era como bonito" Depois da missa "... às vezes chegava um palhacinho também com uns cachorros.” (R. J. 4).

O patrimônio que preserva o centro histórico, em especial, a Paróquia, o Parque Central, a Casa da Cultura, o Fortín, o Correio mantém a materialidade do espaço, como produção histórica, que permitelhe perdurar no tempo a modo de rugosidade, o que é definido por (Santos, 2000) como aquele que “(...) fica do passado como forma, espaço construído, paisagem, o que resta do processo de supressão, acumulação, superposição, com que as coisas se substituem e acumulam em todos os lugares" (p.92). Ou seja, se consideram resquícios de um passado e modo de produção donde podem coexistir muitos passados.

A materialidade do espaço é herdada a outras gerações e cada uma delas integra a outras formas espaciais, de temporalidades posteriores, com as formas de vidas presentes. Isto se logra por meio da funcionalização do espaço, a patrimonialização, a destruição do patrimônio (LINDÓN, 2012).

O cemitério constitui um lugar de estudo para a jovem estudante universitária, as visitas diárias com seu avô ao Cemitério Municipal durante a infância mostram um lugar subalterno donde se constrói a emoção e o sentimento para a morte que tradicionalmente inspira topofobia. No entanto, a nostalgia dessa jovem com relação ao cemitério se explica, porque ali foi onde ela aprendeu a ler, sua curiosidade por apropriar-se simbolicamente do território a motivou a ler as lápides que ali se encontram 
acompanhada de seu avô vão decodificando os nomes de algumas sepulturas. - "Para muitas pessoas é um lugar triste, para mim é uma lembrança, é uma recordação muito bonita que guardo com muito carinho, é algo que compartilhamos meu avô e eu ir ali, com alegria, além disso, foi o lugar onde eu aprendi a ler tudo, por isso também o considero um lugar educativo" (R. J. 7).

Outro lugar que remete à experiência de aprendizagem é o parque público; neste caso o Parque das Índias, conhecido como Parque de las Embarazadas, assim o expressa o jovem professor universitário: - "Sim, desde pequenino, eu sempre gostei muito da literatura e de escrever e nesse parque, quando todas as crianças iam embora eu ficava, porque eu era quem vivia mais perto, então optava por escrever algo, ou ler algum conto da biblioteca ou algo, como para uma pessoa de cinco anos" (R. J. 3).

A Universidade Nacional e sua Biblioteca Infantil constituem um lugar de lembranças, continua o mesmo jovem:

Eu gostava muito desta parte aqui da Universidade... onde está agora o vagão do trem com a biblioteca para crianças... era também como o lugar que me encantava ir... emprestavam os livros às crianças que liam muito e me encantava ler Carmen Lira, então sempre me levavam ali para pegar os contos de Tia Panchita” (R. J. 3). Com respeito à mãe adolescente ela agrega que “...eu tenho muito boas recordações Dali, do prekinder, as professoras... creio que uma se chamava Flory e a outra não me recordo, eram pessoas muito boas... Aí entrei, eu creio, como aos cinco anos por aí, já depois fui ao kínder foi aí na Bráulio, mas o prekinder foi aí no Trencito Infantil" (R. J. 7).

A época de jogos na infância forma parte do imaginário da cidade, muitos deles tradicionais, como "la anda", "muñecas", "jacses", "escondido", "avioncito" "atraparnos...

"Fazíamos duas equipes, quase sempre homens e mulheres, e então os homens agarram as mulheres e quando já estavam todas presas se fazia ao contrário e assim todo mundo corria por toda a escola" (R. J. 4). “... dengue que era um jogo engraçado que se brincava... se bota um limite na metade da rua com duas bocas em cada lado, como uns dois metros de comprimento, se faz uma linha e se coloca duas pessoas ou três ou somente uma, e as demais pessoas tentam 
passar a linha sem tocar na pessoa que estava no centro e se a tocasse então ficava com a pessoa do centro e quanto mais pessoas ficassem no centro aumentava a linha, então ficava mais difícil passar e a que ficasse por último era a que ganhava.” (R. J. 5).

A preferência de ir jogar futebol e ir ao estádio era ressaltada entre os rapazes.

“... nós éramos os que organizávamos as peladas aqui contra outro bairro e eram jogadas aos domingos, então, caso sua mãe dissesse a você que ia à missa as nove no domingo, tudo acabava. Ficávamos torcendo para que fôssemos à missa do sábado às sete. Caso contrário, Não, não! Ficávamos aborrecidos, chateados até domingo, certo? e dizíamos - não, por favor, esperem-me que eu daqui a pouco venho, mas na verdade eu não podia e dizia: - que chato ir à igreja. Então, eu imaginava que, enquanto eu estava na igreja àqueles tipos estavam lá jogando futebol e repetia isso na imaginação: - ora bolas! Que saco! Melhor ir à missa nos sábados às 7. Então eu vinha para a missa com uma senhora, porque a senhora ia aos sábados às 7 , e eu dizia a mamãe - eu vou à missa com esta senhora para que amanhã não tenha que ir, por isso era um lugar que eu não preferia.(R. J. 6).

O cafezal lembra os rapazes de mais idade, um lugar de jogos é onde se encontravam frutas, assim manifesta um jovem "tinha muitas árvores frutíferas, eu recordo de ir colher jambos... Deliciosos... e mangas, laranjas lima e então essa era como a grande aventura e quase sempre ia às férias." (R. J. 3).

Assim mesmo, a zona em torno do novo Hospital de Heredia eram cafezais onde as crianças das zonas do entorno visitavam para comer mangas e outra fruta de temporada.

Nossa! Mais que tudo, quando éramos crianças, íamos colher seriguela, jambos, mangas, guaiava, ou limões... Tudo isso. Então! Nossa! O que fazíamos era: nós levávamos um saco e repartíamos para todos, e então, cada um ia embora com mangas e guaiava e com todos os demais, mais que tudo era isso. Nas sextas-feiras de tarde, quando saíamos, digamos às 12 , então pegávamos um ônibus e íamos jogar bola, depois pegávamos outro ônibus e dizíamos: Caraca! Que gostoso um manguito! Verdade? Nossa! Vamos! Depois eu dizia: - eu sei onde há um pezinho que está cheio de mangas gostosas. Então a gente ia para lá, era como o Facebook dessa época, verdade? Comentava-se onde tinha um monte de pés de manga e todos iam para o 
local e se trazia uns sacões cheios de mangas e tudo era para consumo próprio e também para $\operatorname{dar}($ R. J. 6).

Por outro lado, a praça de esportes no Bairro El Carmen é recordada como um lugar seguro "nós podíamos ficar ali até às dez da noite" (R. J. 1), sempre em companhia dos pais, ali podia jogar futebol ou andar de bicicleta. Ainda que para os amantes do skate não existissem lugares de jogo, nem pista para treinar, e por essa razão, tinha que se deslocar para a periferia da cidade.

Durante a adolescência ocorre um trânsito da Heredia tradicional para um imaginário de uma cidade pós-moderna, onde o sentido de lugar carregado de história e a identidade cultural se transformam em um espaço genérico "O imaginário que se constrói neste contexto não manifesta o mesmo interesse pelo passado e sua cristalização espacial em lugares e monumentos, que aqueles que se costuma plantear-se o imaginário patrimonialista" (HIERNAUX, 2006, p.34).

Os jovens, cuja etapa da adolescência foi entre os anos 2000 a 2005, expressam a transformação do espaço urbano e o impacto da globalização como se mostra na figura 3. Destacam a construção do Shopping Paseo de las Flores, cuja arquitetura neocolonial recria o monumento do Fortín, como atrativo e surge como complemento das visitas a cidade de Heredia. Dessa maneira, a construção do novo hospital dos heredianos e a desaparição dos cafezais que ainda perduravam na cidade. Durante esta etapa permanece a prática de visitar o centro histórico.

Um acontecimento que expressa o impacto da globalização é a desaparecimento das padarias tradicionais, por exemplo, La Cartaginesa "recordo-me que era branca e azul, verdade? Bem! Cheirava delicioso, óbvio! Porque faziam pão" (R. J. 7), assim como outras artesanais. Isto se explica, em grande medida, com o posicionamento no mercado da franquia Musmanni, pertencente à Florida Ice \& Farm Co.

A cidade é cada vez mais comercial e menos residencial 
“... cada vez é menos, cada vez há mais comércios, cada vez há menos gente... por exemplo, nas comidas agora se vê uma coisa que se vende um montão, antes custava, digamos mais, que você dizia vamos a um lado que ali vendem frango e agora por todo lado vendem frango ou ainda os chineses que tem por todo lado, a cada 100 metros tem um chino é assim, não é? E desde quando você pensa que isso mudou?... Ah! como há dez anos" (R. J. 4).

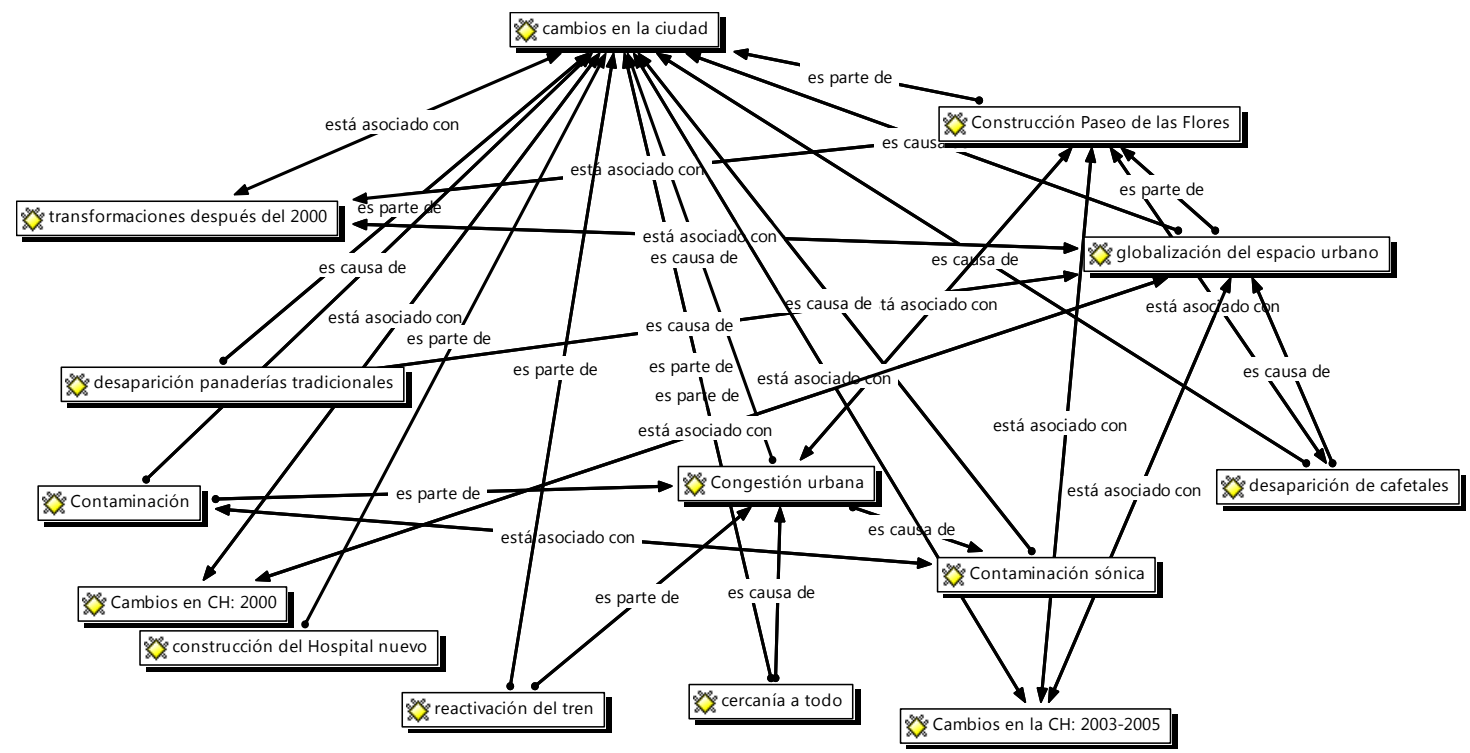

Figura 3. Mudanças na cidade de Heredia, segundo as pessoas jovens entrevistadas, 2015.

O incremento do comercio de comidas rápidas e as franquias influem nas preferências das pessoas jovens (figura 4), desde sua adolescência, por lugares como Taco Bell, Mc Donalds ou a Pizzería Mangiari nas horas de almoço durante os dias com aulas.

“... recordo-me quando nos tocava todo o dia, íamos comer algo no Taco ou McDonalds, porque na Soda a comida não era muito agradável.” (R. J. 7). Atualmente, a entrada para Heredia pela Rua 9 " se tornou muito comercial, digamos que quando eu ia ao McDonalds e assim, recordo-me ver o McDonald e o Taco Bell e agora na frente deles está o Papa Jonhs, o Sub Way e tudo isso já se tornou pura comida que não presta, eu lhe digo que esta é a rua do engorda, digo eu, porque somente vendem porcarias... tudo isso são 200 metros que você só vê comida que não presta” (R. J. 2).

Da mesma maneira, eles mantêm as visitas tradicionais nos tempos de ócio, como sendo a compra de sorvetes na loja dos colombianos para logo permanecer no Parque Central. “... quando havia alguma 
aula que algum professor faltava, ou coisa assim, nós íamos nos sentar no parque e aí ficar brincando, fazendo gozação com os companheiros e quando saíamos cedo íamos tomar um sorvete na sorveteria dos colombianos" (R. J. 7).

Os espaços recreativos para os amantes da patinagem ou o skate são escassos, pelo qual devem trasladar-se fora da cidade para praticá-los.

“... aqui na cidade íamos aos parques, digamos, ao Parque Los Angeles, mas a polícia no botava para fora por causa da patinete, então o policial nos dizia que se insistíssemos ele apreendia a patinete. Bom! assim, quase sempre era um problema com isso, porque não podia andar nos parques procurando escadas, bancos, coisas assim, porque a Polícia nos caia em cima” (R. J. 6). Outra das atividades consiste em frequentar o Estádio Rosabal Cordero.“... eu estava na escola de futebol desde pequeno e depois já comecei a jogar-me para a patinava. Depois ia ao estádio para ver jogar o time, depois conheci amigos e nós íamos aqui com os do bairro, nos reuníamos e descíamos às vezes para jogar bola e depois nós íamos para o estádio e a partida começava as 8 e nós saíamos de lá quase às 10, digamos às 10, pois chegávamos aqui às 10.30" (R. J. 6).

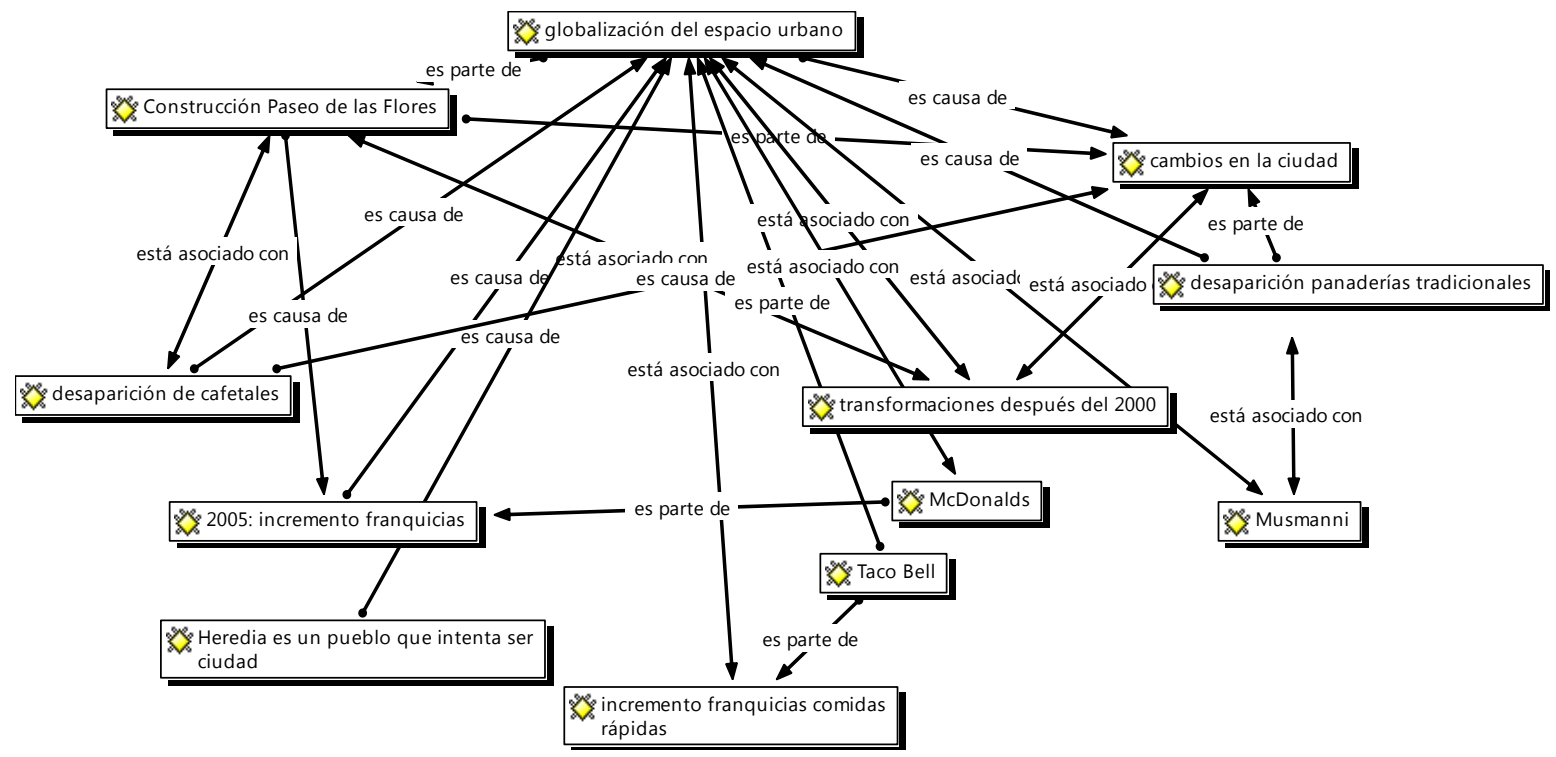

Figura 4. Globalização do espaço urbano, segundo as pessoas jovens entrevistadas, 2015.

No caso da jovem economista e seus parceiros do Colégio Claretiano, eles gostavam de visitar as zonas verdes da Universidade Nacional, e a respeito nos indica: - "Sim! Nós íamos para o teatro de lá e 
assistíamos as obras do teatro grátis. Também havia outros se não me falha a memória eram as sextas-feiras culturais..." (R. J. 1).

A expansão comercial da cidade de Heredia e as mudanças no uso do solo vão incrementando-se pelo norte da cidade, entre Santa Lucía e Barva; assim como até o este colidindo com o município de Ulloa, no caso de Fernando, depois de jogar na praça do Bairro El Carmen, iam para os cafezais próximos, onde atualmente está situado o novo Hospital de Heredia, para comer as frutas da temporada.

As mudanças na paisagem cafeeira são notórias, expressa o jovem professor universitário "digamos que eu sinto que mudou muito,... as zonas verdes,... já se perdeu muito cafezal,... muito lote baldio,... há muita urbanização nova” (R. J. 3). A mudança de uma paisagem cafeeira para outra totalmente urbana se expressa com nostalgia, inclusive com tristeza: "E agora que você vê que já não há mais cafezal quais emoções se desenham diante de você? - Com saudades! As vezes que passo por aqui correndo e vejo que só tem casas, construções, se vê tão seco, como tão... construíram muitas casas e não procuraram fazer uma zona verde, e então, só se vê concreto, muito ruído e tem muita gente...."(R. J. 3).

$\mathrm{Na}$ vida adulta de todos os jovens entrevistados o ambiente de tranquilidade se transforma, quando se movimentam pela cidade durante a noite. Quando as lojas fecham, a cidade se torna insegura e as práticas espaciais de transitar se convertem em estratégias de sobrevivência ante a insegurança cidadã.

\section{Imaginários do medo: acerca da insegurança na cidade de Heredia}

As práticas espaciais associadas à mobilidade e os lugares que frequentam os jovens de tarde e de noite respondem a imaginários do medo. Para Martel \& Baires (2006) estes são: ... invenção pessoal ou coletiva que se faz da cidade construída e que tem fundamento na violência cotidiana da insegurança e 
que permitem que se constitua uma representação determinada dos espaços urbanos, principalmente os públicos. São desde os imaginários do medo que se constituem formas de nomear (e estigmatizar) esses lugares e sujeitos sociais identificados com a insegurança e o risco.

O imaginário do medo se elabora no diálogo entre a insegurança da cidadania e o uso do espaço público dos jovens heredianos, no contexto das cidades latino-americanas. América Latina é caracterizada como a região com mais problemas de desigualdade do mundo. Segundo o Informe Latinbarómetro 2015, a partir de 2008 o problema de delinquência (17\%) supera o desemprego (15\%), em tanto para 2011 obtém um 28\% y descende a 23\% em 2015 (CORPORACIÓN LATINOBARÓMETRO, 2015, $96)$.

Em tanto, em 2015 a vitimização chega aos 44\%, o ponto máximo desde 1995. Os países onde percepção cresce-o formam Venezuela e Brasil, ainda que a maioria das pessoas fosse vitima de delito (89\% y 48\% respectivamente). Em Venezuela o 23\% e Brasil 9\% consideram que a delinquência é a maior problema. Na Costa Rica, o 10\% das pessoas entrevistas pelo Latinbarometro o problema principal é, no entanto a vitimização corresponde a 37\% (CORPORACIÓN LATINOBARÓMETRO, $2015,99)$.

De acordo com os jovens entrevistados a deterioralização dos espaços públicos repercute na insegurança (figura 5), o qual se manifesta na identificação de lugares inseguros donde acontecem assaltos, as características dos lugares, assim como a leitura do entorno para evitar os assaltos.

A percepção da inseguridade é outra variável do Informe pelo Latinbarometro, na Venezuela 84\% das pessoas entrevistadas dizem que é inseguro, em Brasil 77\%, Guatemala com 72\%, Argentina e Peru com 71\% e México com 70\%, e El Salvador com 83\%. Na Costa Rica o 67\% opinam que é inseguro, em tanto seu vizinho Nicarágua tem 28\% (CORPORACIÓN LATINOBARÓMETRO, 2015, 100). 
As vivencias dos jovens relacionados com os imaginários do medo são construídas na vida adulta quando têm aulas da noite as atividades recreativas: "Nunca havia tido que caminhar tão tarde na rua... agora eu tenho muitos amigos estrangeiros que gostam muito de ir aos barzinhos perto da UMA... então eu saia com uma grande paranoia, certo? porque talvez fossem 12 da noite e eles tranquilos, em sua maioria eram centro-americanos, mais como eles estão muito bombardeados de inseguridade, quando chegavam na Costa Rica se sentiam mais bem seguros, mais eu era o que andava paranoico, eles falavam não, nada acontece. Eles eram muito arriscados porque eles iam desde na UMA até Palacio dos Deportes de pé, atravessando o Parque Central, o Liceo de Heredia, uma das zonas que eu sempre evitei (R.J.3).

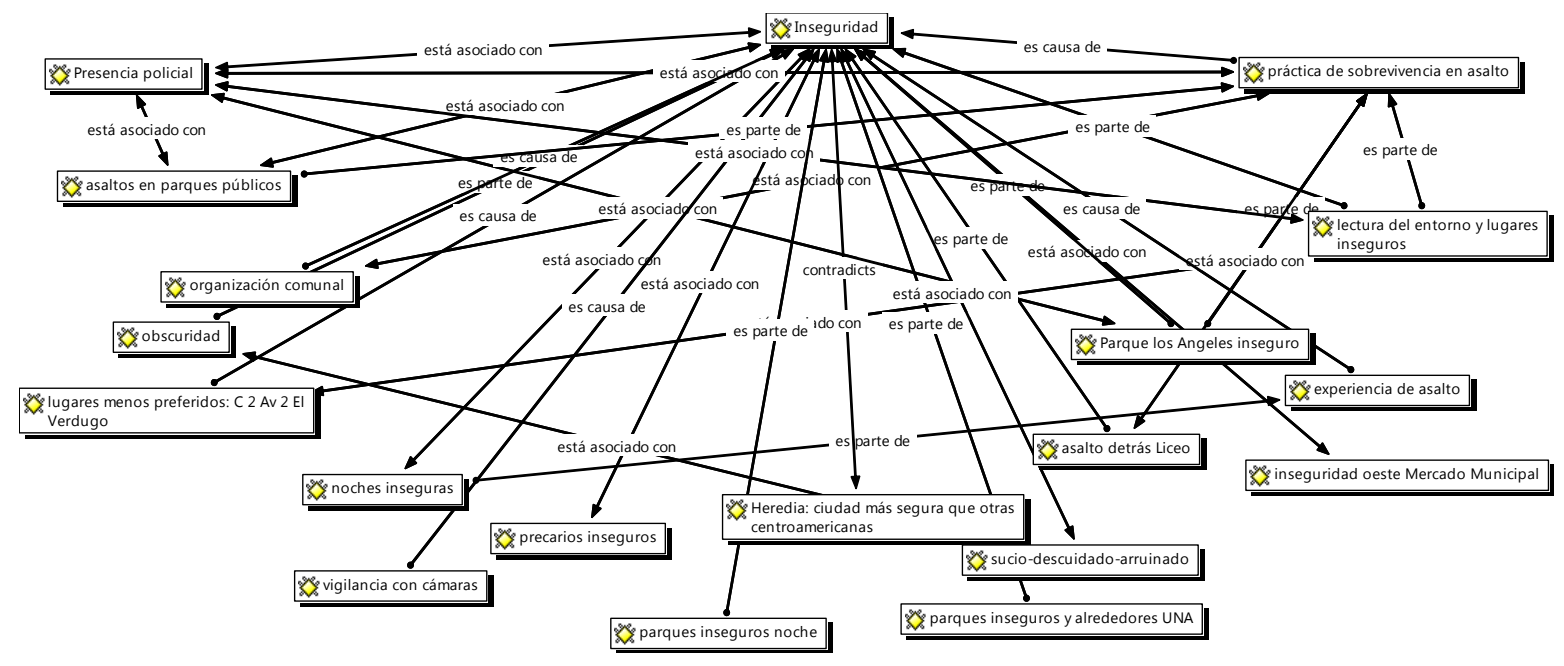

Figura 5. Insegurança na cidade de Heredia, segundo as pessoas jovens entrevistadas, 2015.

Os jovens entrevistados coincidem em que residir na cidade de Heredia tem grandes vantagens, assim o ilustra o R. J. 7, a mãe adolescente: “... é um lugar central, então está ao alcance de tudo: shopping, universidades, transporte público, etc.. Eu sinto que não temos nada que invejar a San José...” Em todos os casos se compara Heredia com San José como um lugar mais inseguro, além de que em Heredia há maior segurança pública e se dispõem de câmaras de vigilância.

A invenção coletiva da insegurança cidadã configura as práticas espaciais de transitar por alguns lugares e descartar outros, ainda não há distinção por gênero com respeito à insegurança em alguns 
lugares, as estratégias de transitar na cidade se alteram nos percursos a pé, caminhar rápido é uma prática frequente:

“... Eu caminho muito rápido, às vezes como entre 9.20 p.m. e 9.30 p.m., vem muita gente, então você se sente como acompanhado pelas pessoas, ainda que não as conheça.” (R. J. 2). "Há zonas que eu gosto de evitar, por exemplo, inclusive atravessar o mesmo parque depois das 9 da noite... Atravessar o Parque Central é algo que eu não faço, eu prefiro ir como os labirintos por dentro de Fátima até a zona para onde vamos para ver como seria aí, é que antes era onde paravam os ônibus para San Pedro de Barva, essa rua é, sabe onde fica a loja Arenas? Como essa rua para baixo que agora puseram como muitos bares... também aí, não sei... como que há muita gente esquisita, então esses lugares eu sempre os evito, quase que o que eu evito é o puro centro, eu prefiro, quando vou tarde para minha casa, não ir por essas zonas, ir pelos bairros, ir por Fátima e como por estas ruazinhas onde estão as casas, apesar de que tenha que passar aí pelo bar El Botecito, o Bar Fátima, mas, que eles são muito mais tranquilos, então eu passo bem tranquilo por aí. (R. J 3).

A leitura do entorno urbano implica práticas de deslocamentos mais longos como uma forma de prevenção. “... digamos... se vejo que a rua é muito perigosa ou - Nossa! Não sei ou é um lugar muito conflitivo, então eu prefiro evitá-lo, e passar por outro, caminhar mais 100 metros, dar a volta, mas não passar por aí, absolutamente". (R.J. 6).

No caso das mulheres, elas preferem percorrer a cidade em companhia de outras pessoas, inclusive no caso de Carolina, ela evita caminhar só pela cidade, tanto de dia como de noite.

Em geral, durante as noites, as pessoas jovens não circulam nos parques públicos, em especial no Parque de Los Ángeles, razão porque ninguém reporta um assalto nesta zona, apesar desse lugar ser considerado como “... a caverna da delinquência”... "Ave Maria! porque tem muitos bêbados, viciados em drogas e quase não tem policiamento. É um parque que durante a noite é sem segurança, porque não há segurança pública, nem há luz, nem nada, então é como muito... É como o pior de Heredia. Ainda bem que já vão reurbanizá-lo" (R. J. 7). Para MARTEL \& BAIRES (2006) nestes elementos descritos correspondem a ameaças do entorno como acontece no Salvador 
A deterioração dos espaços públicos e a falta de vigilância incidem nas características dos lugares perigosos que se associam com a escuridão da noite quando o comércio fecha suas portas. Com referência ao Parque Los Ángeles um relato expressa que: "É que como é muito feio, muito abandonado, muito deserto e com muitos assaltos... Sim, por isso eu não passo por aí, não me arrisco, mas dizem que... eu tenho visto que há como muita gente esquisita de noite e assim, também é escura e só se vê casais sentados no parque. (R. J. 4). Para MARTEL \& BAIRES (2006, p. 122): "Os espaços públicos, além de lugares de encontro, são espaços de desencontros e insegurança”.

Dos sete jovens entrevistados, dois deles foram assaltados, o qual corresponde com a percepção nacional da vitimização, segundo Informe de Latinbarometro 2015. No caso a jovem economista foi assaltada duas vezes no Parque El Carmen, a primeira vez de tarde e a outra tarde da noite. A experiência de viver na cidade de Heredia outorga-lhes um conhecimento daqueles lugares por onde mobilizar-se com segurança, assim o expressou uma jovem “... em Heredia já se sabe por aonde ir e vir, porque já se sabe onde são as zonas perigosas, certo?" (R. J. 1).

Ao consultá-la acerca do segundo assalto perguntei "I: Mas, digamos"... Os casos de assalto só aconteceram com você, em sua casa, ou com suas irmãs ou com seus pais? Só assaltaram você?

R.J.1: Não! Só a mim. Bom! Na realidade foi ao meu ex-namorado, porque eu tinha a bolsa de minha irmã e ela me disse do Bule: vão para casa! Nós viemos por aqui, coisa que eu nunca faço, eu nunca venho pelo Parque El Carmen, eu desço lá no Verdureiro e venho pela bomba e aí como tem tanto táxi, aproveitamos e tomamos um. Vínhamos do Bulevar com um monte de dinheiro em espécie que minha irmã tinha sacado e me disse: vá para casa, então chegaram e me colocaram a pistola e meu exnamorado teve que dar tudo.

I: Mas você andava com a bolsa da sua irmã?

R.J.1. Eu a coloquei para trás, inteligentemente, e me encostei-me a ela... Morta de medo, porque, Ave Maria! Eu tinha a pistola aqui.

I: Por que só levaram as coisas dele? Porque não viram sua bolsa, suas coisas? 
R: J. 1. Não, o meu não, eles eram inexperientes! Eles apareceram de repente... Pelas nossas costas... Viram-nos... Éramos para eles como pintinhos, porque eram às 11 da noite e vínhamos cruzando o parque.

O caso do jovem professor universitário é diferente, porque ele e seu amigo foram assaltados ao descer de um táxi: "Isso foi? quando foi? 2010... que tinha um amigo que precisamente vivia perto do Palácio de los Deportes,... eu o havia convidado para assistir uma palestra em minha classe e saímos muito tarde nesse dia; a aula começava as 6 e talvez nós tenhamos regressado como às 10 da noite. Íamos de taxi e, quando nós descemos do táxi.... o táxi nos deixou aqui..., a casa estava aqui...., no momento nós fomos cruzar a calçada para entrar em casa, nós dois fomos assaltados (R.J.3).

I: A mão armada?

R: J. 3. Sim, mas essa foi à única vez que me assaltaram.

I: E por isso toma essas precauções nos itinerários?

R: J. 3. Sim, exato, pelos caminhos alternativos, porque parece mentira, mas eu prefiro passar pelos lugares mais desertos de Heredia, porque sinto que são mais seguros, porque nos mais movimentados é onde estão as pessoas mais esquisitas. (R. J. 3).

É claro que ambos jovens possuem um conhecimento profundo da cidade e podem ter uma reação de forma racional em situações de insegurança. No caso de todos os jovens entrevistados eles incorporaram práticas espaciais em relação a sua segurança. Com respeito ao jovem professor ele nos indica que: "não gosto de andar pelas mesmas ruas... se porventura estão me seguindo... ainda que nunca saia com nada de valor" (R. J. 3).

Os lugares pelos quais se transitam, formam parte do imaginário do medo e a prática específica se relaciona com as ruas e zonas públicas donde transitar para evitar as possibilidades de assalto.

A construção do imaginário da cidade está vinculada às práticas socioespaciais na cotidianidade imaginada ao longo da vida, além disso, respondem às atividades a um conhecimento profundo da cidade. Na figura 6 mostra-se a frequência dos delitos na cidade, de acordo com o ponto onde foram 
reportados. É claro que os parques declarados como inseguros pelos jovens entrevistados correspondem àqueles com maior quantidade de delitos: o Parque Central, Parque de Los Ángeles, El Parque del Carmen e o Parque de Las Embarazadas ("das grávidas"). No entanto as zonas residenciais aparecem como de maior segurança.

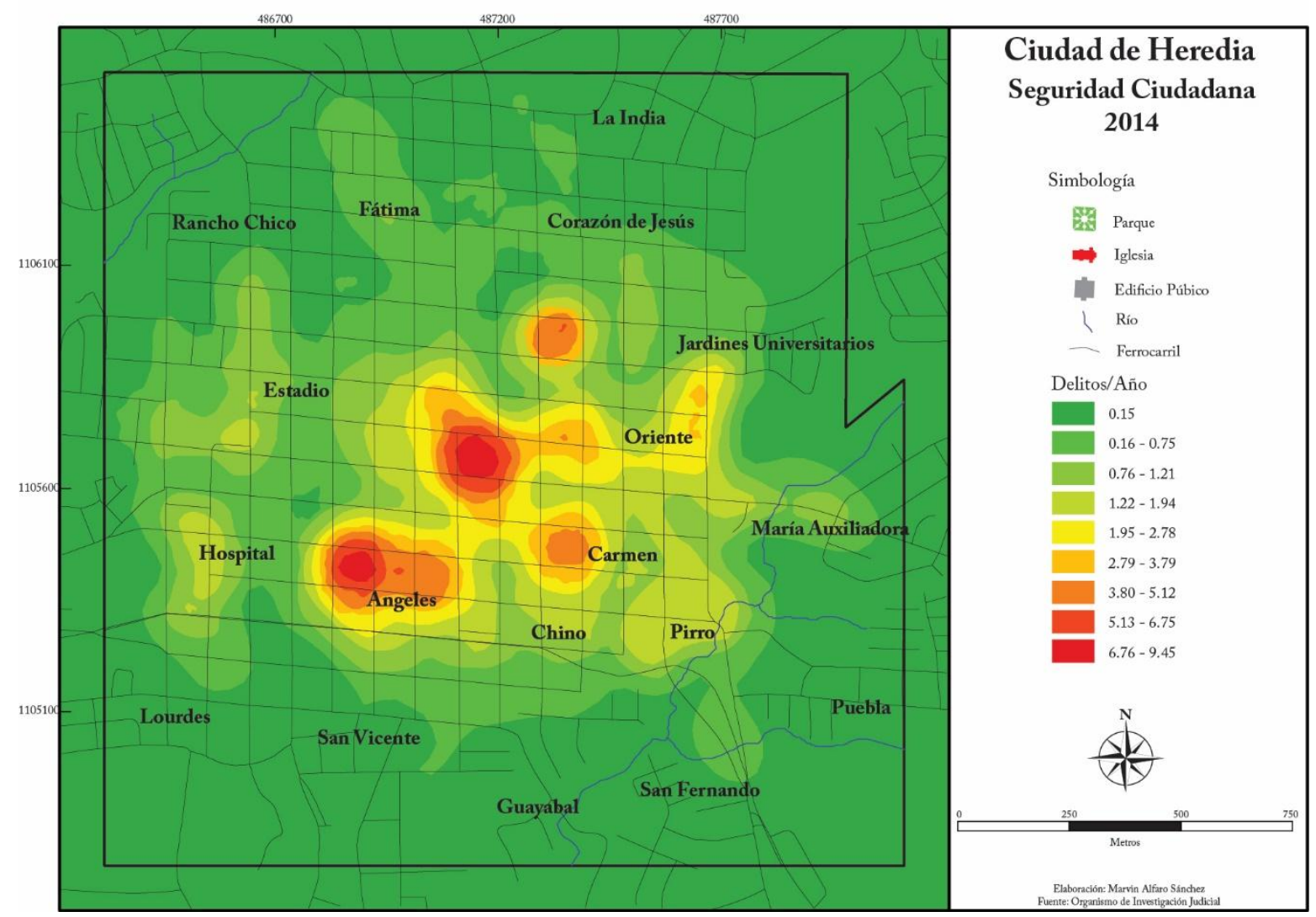

Figura 6. Insegurança cidadã, segundo a frequência de delitos na cidade de Heredia, 2014.

\section{Considerações finais}

As práticas socioespaciais recriam os diversos imaginários urbanos desde as perspectivas dos jovens que narram suas histórias e seu passado imaginando o futuro. Os imaginários configuram as construções subjetivas e intersubjetivas donde os elementos afetivos e emocionais estruturam as práticas de habitar os lugares. Isto o explica CANCLINI (1999) quando afirma que na atualidade ao cultural, o simbólico, o complexo e heterogêneo tem muita importância, então o imaginado é um 
componente fundamental de uma cidade heterogênea, porque apresenta muitos imaginários das pessoas que habitam.

Os relatos retratam a experiência de habitar a cidade de Heredia, a qual está inserida em uma megalópole e segundo as práticas no espaço urbano prevalecem diversos imaginários.

O imaginário patrimonial: Ainda em 1706 Heredia era uma vila, uma cidade colonial que nasceu em torno de um templo católico, em 1824 com uma população de 2000 pessoas se converteram em uma cidade (ZAMORA, 2011, MELÉNDEZ, 2001). Uma cidade cafeteira onde ainda perdura os principais símbolos do imaginário urbano dos jovens, o Parque Central com sua igreja, sua fonte e ó Fortín. A infância dos entrevistados lembra os usos dos espaços públicos para brincar, eles elaboram uma produção de seu próprio espaço cotidiano.

Os jovens constroem diversos imaginários da cidade, mais o imaginário patrimonial é parte da infância de todos os entrevistados. O Centro Histórico da cidade e suas edificações permanecem como rugosidades de tempo passado quando Heredia era um povoado cafeteiro. A transformação da cidade depois dos anos noventa configura as atividades dos jovens no uso de espaço privado. Os contrastes entre os usos do espaço são notórios, a infância está associada ao espaço público.

Imaginário cafeteiro: A atividade cafeeira que iniciou na terceira década do século XIX explica o fortalecimento da população urbana e seu desenvolvimento. Os jovens lembram os fragmentos das plantações de café em que permaneceram até 2005 e foram substituídos por shoppings e urbanizações. Mais prevalecem costumes quando a cidade era um povoado, de ali a frase "Heredia por media calle" um povoado sim calçadas donde as pessoas tinham caminhado pela rua. A localização que oferece a cidade é ótima para o desenvolvimento das atividades comerciais em uma sociedade terciaria.

Imaginário comercial: "Um povoado que quer ser uma cidade" expressa o jovem professor, o seja, um povoado cafeteiro com uma ótima localização que e transformado em uma cidade com grandes 
vantagens, porque tudo está próximo, mais com desvantagens das grandes cidades de América Latina. Uma cidade pequena como acontece em Heredia favorece a experiência espacial das pessoas, assim como a permanência e identidade da Heredianidad. Mas segundo os jovens entrevistados é depois de 2000 a cidade apresenta uma presença de comércios e franquias de empresas transnacionais.

Nesta cidade, como acontece em outras cidades latino-americanas às pessoas vive a tensão entre as tradições que ainda permanecem, neste caso, cada domingo os torcedores da Club Sport Herediano visitam o estádio, também as pessoas escutam a Orquestra Filarmônica de Heredia, depois da missa de domingo pela manhã. A coexistência de vários modelos de desenvolvimento nestes países gera congestionamento e comunicações deficientes (CANCLINI, 1999).

Imaginário da inseguridade Os jovens entrevistados experimentam a tensão entre o real e o imaginado, em sua experiência como adultos eles disfrutam a vida da noite e o perigo percebido e vivido. Assim, eles desenvolvem estratégia da sobrevivência na cidade donde apresenta estereotipo geográficos de aqueles lugares do medo. A inseguridade cidadania que acontece na Costa Rica e percebida pelas pessoas jovens, as quais são capturadas nos microcosmos das cidades. Os imaginários correspondem a elaborações simbólicas de aquilo que observamos o que nos atemoriza (LINDÓN, 2009, CANCLINI, 1999).

O método utilizado neste artigo a partir dos relatos de vida permite obter varias conclusões:

O enfoque qualitativo proporção uma forma de fazer a reconstrução dos imaginários urbanos da cidade de Heredia obtida a partir das lembranças das pessoas jovens que tinham vivido uma forte transformação da megalópole da Grande área metropolitana de Costa Rica. As perguntas que orientam os relatos permitem obter informação abundante das praticas sócio-espaciis que eles realizam no cotidiano, a emergência de outros temas requer de delimitação dos temas. 
Finalmente, o caminho indutivo oferece os dados para gerar uma hipótese relacionada com a forma como os processos de megapolização da Grande área metropolitana modificam as práticas socioespaciais dos jovens na cidade de Heredia e influi a construção dos imaginários da vida adulta e sua experiência espacial? Ainda é necessário aprofundar aspetos do mestreou para chegar ao ponto de saturação e conhecer a perspectiva da outras pessoas que habitam a cidade em condições de desigualdade social ou condições de exclusão. Os resultados da interpretação dos relatos oferecem os indícios para aprofundar outras temáticas.

\section{REFERÊNCIAS}

BERTAUX, Daniel. Los relatos de vida: perspectiva etnosóciológica (tradução de Godofredo González). Barcelona: Editions Bellaterra, 2005. 143p.

CANCLINI, Néstor. Imaginarios urbanos. Editorial Eduba: Buenos Aires, 1999. 149p.

CARRILLO, Guadalupe. Miradas de la ciudad: la representación del imaginario urbano en el discurso literario latinoamericano de mediados del siglo XX. Universidad Autónoma del Estado de México, 2011. 246p.

CORDERO, Allen. Paisajes y relatos de vida. Apuntes para la interpretación de los paisajes socioculturales con mención a Puntarenas y Limón (centro) en Costa Rica. Praxis , n. 16, 2014. p 9-30.

CORPORACIÓN LATINOBARÓMETRO Latinobarómetro opinión pública latinoamericana. Informe 1995-2015. Santiago, Chile. 2015. Disponível em http://americanuestra.com/wp-content/uploads/2015/09/INFORME-LB-2015-3.pdf

ELZ, Rubén. La antropología filosófica desde la perspectiva de la complejidad, como posibilitadora de un nuevo diálogo educativo. Memorias del programa científico Universidad. 2010.

GURDIÁN, Alicia. El paradigma cualitativo en la investigación Sócio-Educativa. Coordinación Educativa y cultural Centroamericana. Agencia española de Cooperación internacional. San José, Costa Rica. 2007. 265p.

HIERNAUX, Daniel. Los imaginarios urbanos: de la teoría y los aterrizajes en los estudios urbanos. Eure (Santiago), 33(99), 2007, p.17-30. Disponível em http://www.scielo.cl/pdf/eure/v33n99/art03.pdf

HIERNAUX, Daniel. Los centros históricos: ¿espacios postmodernos? (De los choques de imaginarios y otros conflictos). En LINDÓN, Alicia; AGUILAR, Miguel Ángel \& HIERNAUX, DANIEL. (coords). Lugares imaginarios en la metrópolis. México: Arthropodos. 2006, p 27-41

JANOSCHKA, Michael. El nuevo modo de la ciudad latinoamericana: fragmentación y privatización. EURE, 2002 , v. XXVII, nº 85), p.11-29.

JANOSCHKA, Michael. Geografías urbanas en la era del neoliberalismo. Una conceptualización de la resistencia local a través de la participación y la ciudadanía urbana. Investigaciones geográficas, 2011, n 76, 118-132.

LEFEBVRE, Henry. La producción del espacio (Tradução Ion M. Lorea). Madrid: Capitán Swing, 2013, 451p. 
LINDÓN, Alicia. Los imaginarios urbanos e el constructivismo geográfico: los hologramas espaciales. Eure (Santiago), 2007, v 3, n 99, p.31-46. Disponível em http://www.scielo.cl/pdf/eure/v33n99/art04.pdf

Las geografías constructivistas a las narrativas de vida espaciales como metodologías geográficas cualitativas.

Revista da ANPEGE, 2008, v 4, 7-26p. Disponível em http://anpege.org.br/revista/ojs-

2.2.2/index.php/anpege08/article/view/8/pdf2

La construcción socio espacial de la ciudad: el sujeto cuerpo y el sujeto sentimiento. Revista Latinoamericana

de Estudios sobre Cuerpos, Emociones y Sociedad, 2009, n 1, 06-20.

La concurrencia de lo espacial y lo social. En GARZA, Enrique de la. \& LEYVA Gustavo. (Eds.). Tratado de metodología de las ciencias sociales: perspectivas actuales. México: FCE, UAM -Iztapalapa, 2012, p.585-622:

LINDÓN, Alicia, \& HIERNAUX, Daniel (Dirs). Geografías de lo imaginario. México: Anthrópos: Universidad Autónoma Metropolitana, 2012, 251p.

LINDÓN, Alicia; AGUILAR, Miguel Ángel \& HIERNAUX, DANIEL (coords). Lugares e imaginarios en la metrópolis. México: Anthrópos. Universidad Autónoma Metropolitana, 2006, 219p.

MARTEL, Roxana \& BAIRES, Sonia. (2006). "Imaginarios del miedo y geografías de inseguridad: construcción social y simbólica del espacio público en San Salvador.” En LINDÓN, Alicia; AGUILAR, Miguel Ángel \& HIERNAUX, DANIEL (coords). Lugares e imaginarios en la metrópolis. México: Anthrópos. Universidad Autónoma Metropolitana, 2006, 119$135 \mathrm{p}$.

MELÉnDEZ, Carlos., \& RAMÍREZ, Mario. Añoranzas de Heredia. Heredia. Costa Rica: EUNA, 2001, 123p.

MILLÁN, Mercedes. La geografía de la percepción: una metodología de análisis para el desarrollo rural. Papeles de Geografía 40 (2004), 133-149p.

NIETO, Raúl. Lo imaginario como articulador de los órdenes laboral y urbano. Alteridades, v 8, n 15(1998), 121-129p.

PORTES, A., Roberts, B. R., \& Grimson, A. (coord). (2008). Ciudades latinoamericanas: un análisis comparativo en el umbral del nuevo siglo. Prometeo libros.

SANTOS, Milton. La naturaleza del espacio. Madrid: Espasa-Calpe, S.A. 2000.

STRAUSS, Anselm. \& CORBIN, Juliet. Bases de la investigación cualitativa: técnicas y procedimientos para desarrollar la teoría fundamentada. Universidad de Antioquia, 2002.

TUAN, Yi-Fu Topofilia: Un estudio de las percepciones, actitudes y valores sobre el entorno (Tradução Durán Flor). Melusina; España, 2007, 351p.

ZAMORA, Carlos. Circuito de turismo cultural: Ciudad de Heredia. San José: Costa Rica. Ministerio de cultura y Juventud. Centro de Investigaciones y Conservación del patrimonio Cultural. 2011. 